Acta vet. scand. $1974,15,381-397$.

From the Department of Medicine II, Royal Veterinary College, Stockholm, Sweden.

\title{
SOME ACUTE METABOLIC EFFECTS OF PARATHYROID HORMONE IN SHEEP
}

By

\author{
J. Persson and J. Luthman
}

\begin{abstract}
PERSSON, J. and J. LUTHMAN: Some acute metabolic effects of parathyroid hormone in sheep. Acta vet. scand. 1974, 15, 381-397. It is now well established that calcium ions play a key role in the activation of many different cell systems. Parathyroid hormone (PTH) causes a shift of calcium into bone cells, and lipolytic hormones have little or no effect in calcium-free media. In the present investigation sheep were used to study the acute effects of intravenous injection of bovine PTH on mineral and lipid metabolism. A significant initial hypocalcaemia was found in all groups of animals. The subsequent rise in plasma calcium was most pronounced in rams. Thyroidectomized animals showed a greater calcium response than did intacts. PTH was found to have a strong lipolytic effect, comparable to that of catecholamines, and a slight hyperglycaemic effect. The rise in plasma NEFA was blocked by nicotinic acid, while the hyperglycaemia was potentiated. Hypophosphataemia was obtained in young rams but not in young ewes, and in elder ewes a slight increase in the plasma phosphate level was found. Plasma magnesium decreased in all groups after PTH injection, while PTH + nicotinic acid caused a rise in magnesium concentration. The results are discussed in the view of current knowledge of mineral and lipid metabolism.
\end{abstract}

parathyroid hormone; hypocalcaemia; lipolysis; s h e e p.

The major function of parathyroid hormone (PTH) is to maintain the calcium concentration of the extracellular fluid within physiological limits. This funotion is achieved by the action of the hormone on bone, intestine and kidneys. PTH-induced hypercalcaemia is mainly a result of increased bone resorption. In earlier studies it was often found that intravenous injection of parathyroid extract (PTE) caused an initial fall in plasma calcium before the well known hypercalcaemia occurred 
(Copp \& Cameron 1961, Copp et al. 1962, Tiselius et al. 1964, Haas et al. 1965, Care et al. 1966). This transient hypocalcaemia was generally attributed to impurities of the extracts, mainly calcitonin, since at that time it was not yet established that calcitonin is a hormone of thyroid and not of parathyroid origin. It is now verified that the initial hypocalcaemia following intravenous injection of PTH is caused by the hormone per se. Parsons et al. (1971), Parsons \& Robinson (1971) and Robinson et al. (1972) showed that highly purified PTH caused a slight hypocalcaemia in dogs and rats after intravenous injection. Hypocalcaemia lasted for about $15-20 \mathrm{~min}$. and was followed by the characteristic hypercalcaemic response. It was also verified that hypocalcaemia was associated with increased uptake of calcium in bone. Several workers had previously showed in vitro that PTH causes a shift of calcium into its target organs (for a review see Rasmussen 1972).

The hypercalcaemic response to exogenous PTH varies between species and is related to the responsiveness of the target organs and to the efficacy of the feed back calcium regulation. Ruminants have for a long time been regarded as rather unresponsive, and the physiological significance of PTH in these animals has been questioned. Lotz et al. (1954) reported that daily injections of PTE during a period of 7 days did not change plasma calcium in sheep, and Stott \& Smith (1957) found that thyroparathyroidectomized cows survived partiturition and subsequent lactation without signs of parturient paresis. Jackson et al. (1962) obtained no changes of serum calcium in cows when PTE was administered within $2 \mathrm{hrs}$. after parturition. On the other hand, Todd et al. (1962) noted a $15 \%$ rise in serum calcium when PTE was given to thyroparathyroidectomized cows, and similar results were reported by Mayer et al. (1967) and Martig \& Mayer (1973). These conflicting results may in part be explained by different doses used and the various routes of administration.

The primary aim of the present investigation was to study the acute changes in the plasma levels of calcium, inorganic phosphorus and magnesium in sheep after intravenous injection of PTH. The hyperglycaemic and lipolytic effects of PTH were also studied since it was recently reported by Werner \& Löw (1973) that bovine PTH showed lipolytic effect in vitro. 


\section{MATERIAL AND METHODS}

The acute changes in the plasma levels of calcium, inorganic phosphorus and magnesium after intravenous injection of bovine PTH were studied in 4 groups of sheep, young intact ewes (910 months old), young intact rams ( $9-10$ months old), young thyroidectomized rams and adult ewes ( $3-5$ years old). The female animals were all non-pregnant and non-lactating. All animals were of the Swedish landrace. The animals were kept indoors and fed hay and grain twice daily. The weights ranged from 25 to $56 \mathrm{~kg}$. The animals were not fasted when used in the experiments.

Thyroidectomy was performed as described earlier (Luthman et al. (1972 a). PTH was administered about 24 hrs. after surgery.

Bovine PTH was obtained from Sigma Chemical Company, St. Louis, USA. The preparation contained 200 USP units/mg. The powder was dissolved in a vehicle containing $1 \%$ sodium acetate, $0.5 \%$ l-cysteine hydrochloride and $0.1 \%$ crystalline bovine serum albumin (Fraction $\mathrm{V}$ powder), $\mathrm{pH}$ was adjusted to 4 as recommended by Parsons \& Potts (1972). The PTH solution was made up on the same day it was used and was stored in a refrigerator until just before start of the experiment. The dose of PTH used in all animals was $30 \mathrm{USP}$ units/kg. The control animals received only the vehicle.

The lipolytic and hyperglycaemic effects of PTH were tested only in adult ewes. One group of animals received only PTH and a second group was given PTH and nicotinic acid. Nicotinc acid (5 $\mathrm{mg} / \mathrm{kg}$ ) was given immediately before PTH. The nicotinic acid injection was then repeated after 30 and $60 \mathrm{~min}$.

To avoid excitement of the animals during injections and blood sampling, plastic cannulas (Braunüle 2L, Braun, Melsungen, Germany) were inserted in the jugular veins several hours before start of the experiment. Blood was sampled in heparinized tubes (Heparinrör, Vitrum, Stockholm, Sweden). Plasma was separated within 30 min. after sampling and was stored frozen at $-20^{\circ} \mathrm{C}$ until analysed.

The pretreatment level of the measured parameters given in figures and tables is the mean of 2 determinations. The first determination was made on plasma sampled 30 min. before PTH injection and the second determination on the sample obtained immediately before the injection. 
Calcium was determined according to Skerry (1965) and nonesterified fatty acids (NEFA) according to Dole (1956).

Commercial reagents were used for the determination of glucose (Glox novum, AB Kabi, Stockholm, Sweden), inorganic phosphorus (Sigma Kit 670, Sigma Chemical Company, St. Louis, USA) and magnesium (Merckotest Magnesium, E. Merck, Darmstadt, Germany).

Conventional statistical methods were used (Student's t-test).

\section{RESULTS}

The changes in plasma calcium in intact young sheep after intravenous injection of PTH are shown in Figs. 1 and 2. There was a significant initial hypocalcaemia both in rams and ewes. Hypocalcaemia was followed by a slight hypercalcaemia response. The rise in plasma calcium was most pronounced in the rams.

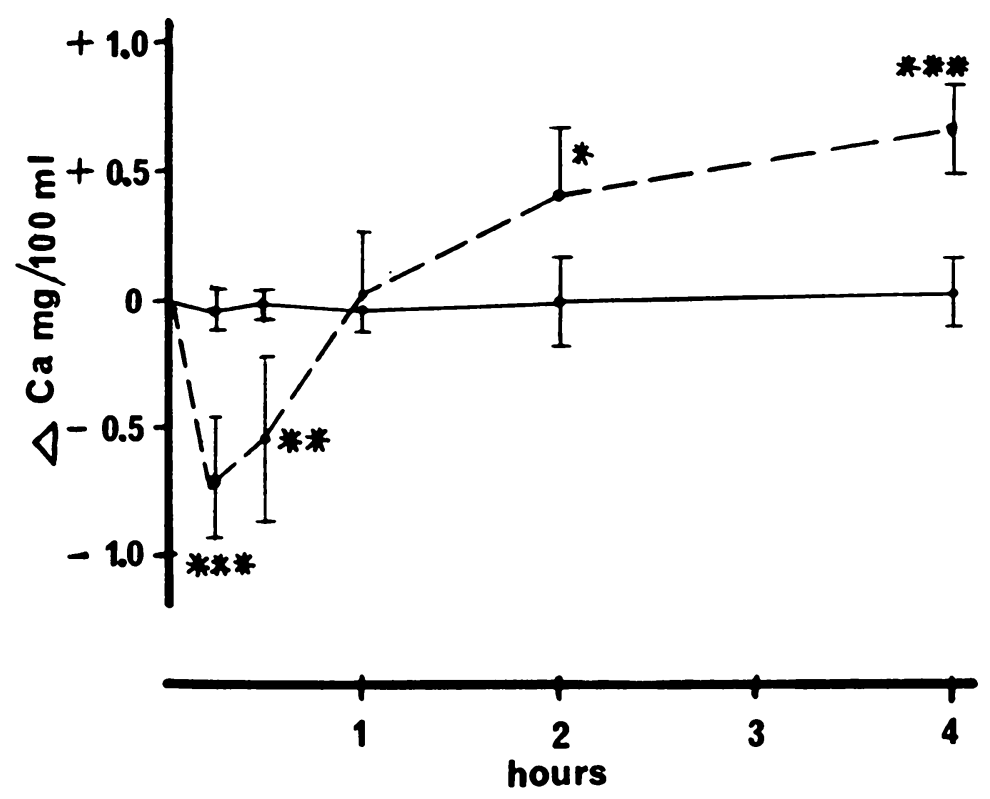

Figure 1. The plasma calcium response in young rams $(n=6)$ to i.v. injection of bovine PTH (30 USP units/kg) - - Controls $(\mathrm{n}=6)$. The preinjection level was $10.22 \pm 0.51 \mathrm{mg} / 100 \mathrm{ml}$ in the PTH group and $10.00 \pm 0.63 \mathrm{mg} / 100 \mathrm{ml}$ in the control group. Mean $\pm s$.

$* 0.05>\mathrm{P}>0.01$

* $0.01>P>0.001$

${ }^{*}{ }^{*} \mathrm{P}<0.001$ 
Statistical comparison between rams and ewes showed an almost significant difference in calcium response $4 \mathrm{hrs}$. after the injection $(0.05>\mathrm{P}>0.01)$.

As shown in Fig. 3, PTH caused a marked increase in plasma calcium in the thyroidectomized rams. The hypercalcaemic response was greater than in the intact animals and occurred earlier. The highest calcium levels were obtained 2 hrs. after the hormone injection.

The changes in inorganic phosphorus and magnesium in intact and thyroidectomized young rams are given in Table 1. PTH caused a significant reduction of the plasma levels of both magnesium and inorganic phosphorus in the intact animals. The thyroidectomized group consisted of only 4 animals, and no statistical calculations were made.

Table 2 shows the changes in inorganic phosphorus and magnesium in young ewes. Inorganic phosphorus did not change, but the magnesium level decreased significantly.

PTH showed a hyperglycaemic effect in the adult ewes and,

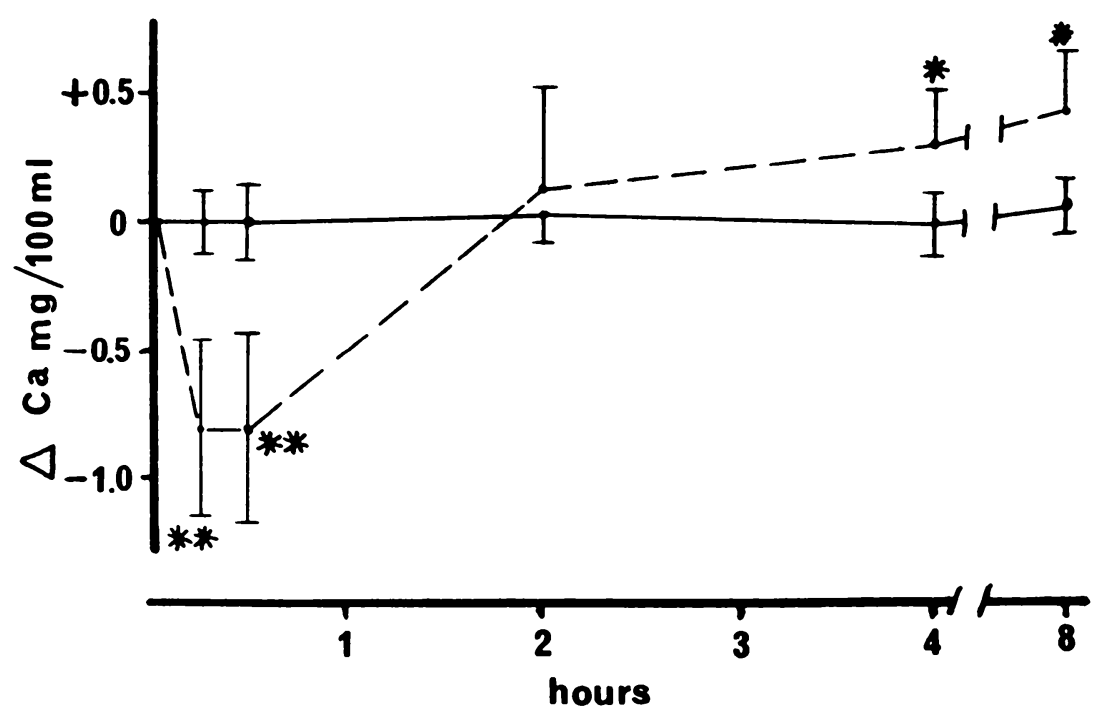

F ig u re 2. Changes in plasma calcium in young ewes $(n=5)$ after i.v. injection of bovine PTH (30 USP units/kg) - - - Controls $(n=5)$ Preinjection level was $10.38 \pm 0.75 \mathrm{mg} / 100 \mathrm{ml}$ in the PTH group and $9.84 \pm 0.52 \mathrm{mg} / 100 \mathrm{ml}$ in the control group. Mean $\pm s$.

$0.05>\mathrm{P}>0.01$

* $0.01>\mathrm{P}>0.001$ 
as shown in Fig. 4, hyperglycaemia was potentiated by nicotinic acid.

As shown in Fig. 5, PTH showed a remarkable lipolytic effect, which, however, was completely abolished by nicotinic acid.

Changes in the plasma levels of calcium, inorganic phosphorus and magnesium in adult ewes after injection of $\mathrm{PTH}+$ nicotinic acid are summarized in Table 3. A small initial reduction of plasma calcium occurred, but calcium increased significantly only in the animals given PTH + nicotinic acid. PTH caused a slight increase of inorganic phosphorus. Plasma magnesium decreased after PTH injection, while PTH + nicotinc acid caused a significant rise in magnesium.

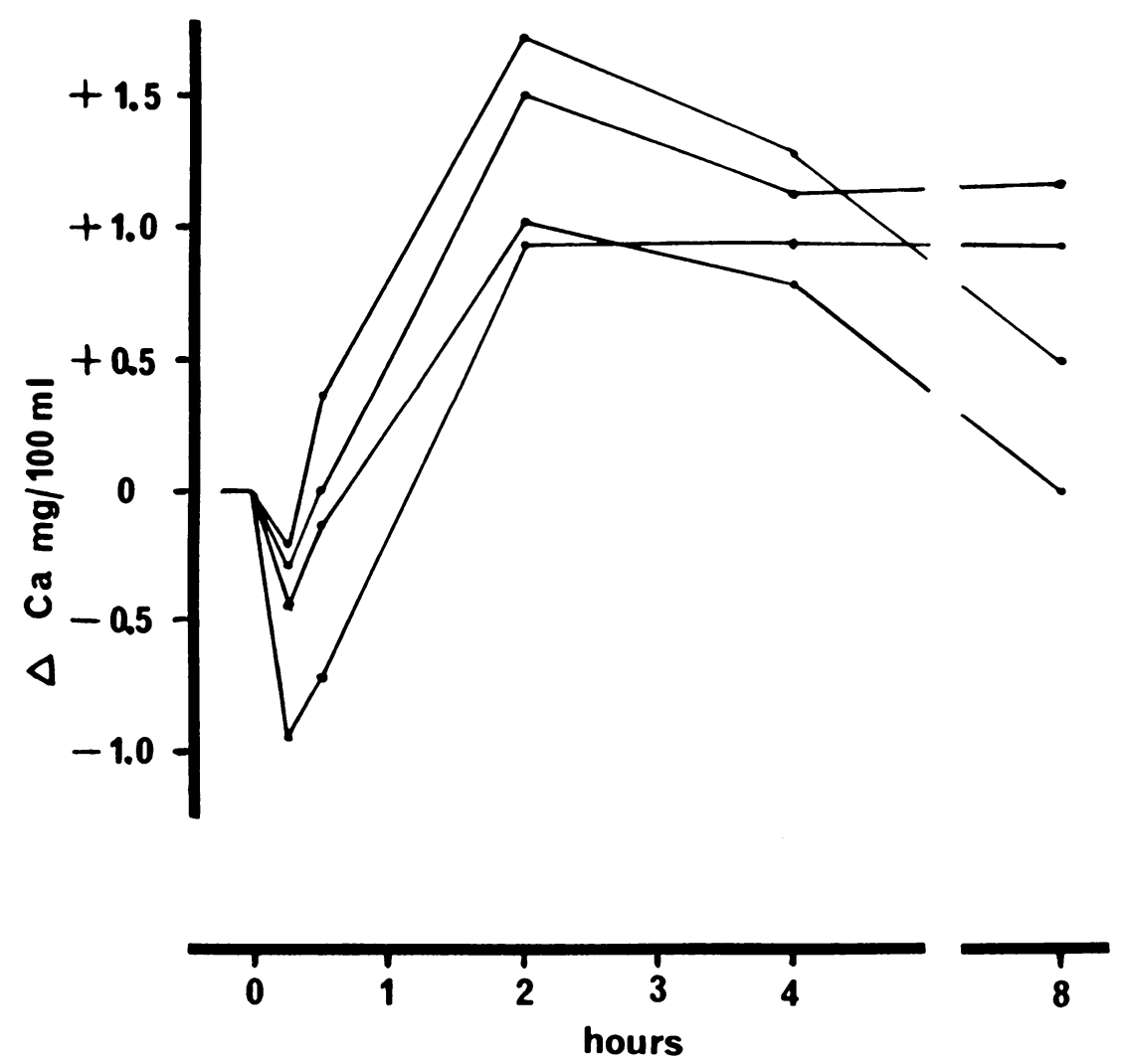

F ig u re 3. The plasma calcium response to bovine PTH (30 USP units $/ \mathrm{kg}$ ) in thyroidectomized rams. Preinjection level was $10.30 \pm 0.47$ $\mathrm{mg} / 100 \mathrm{ml}$. 


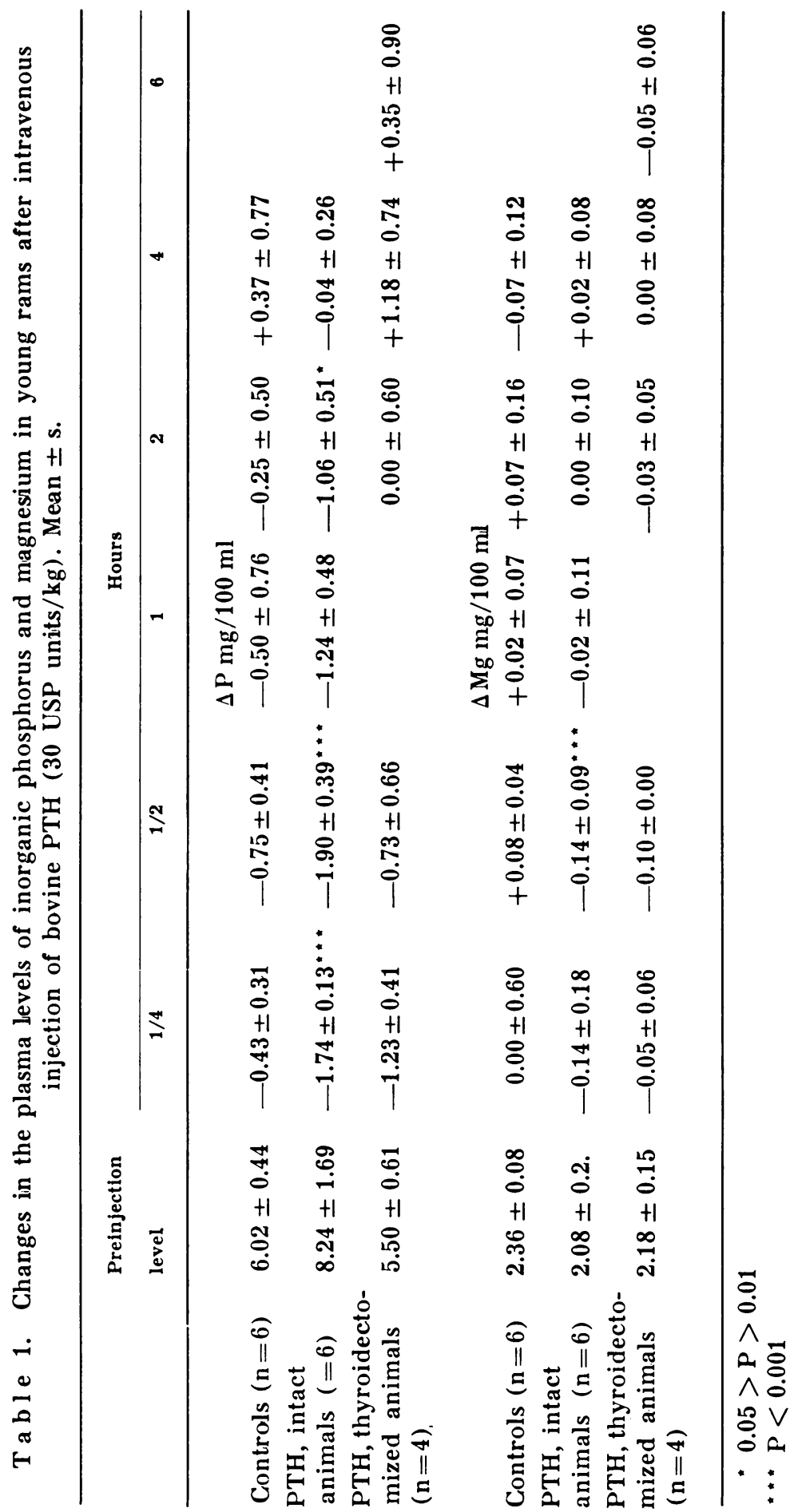




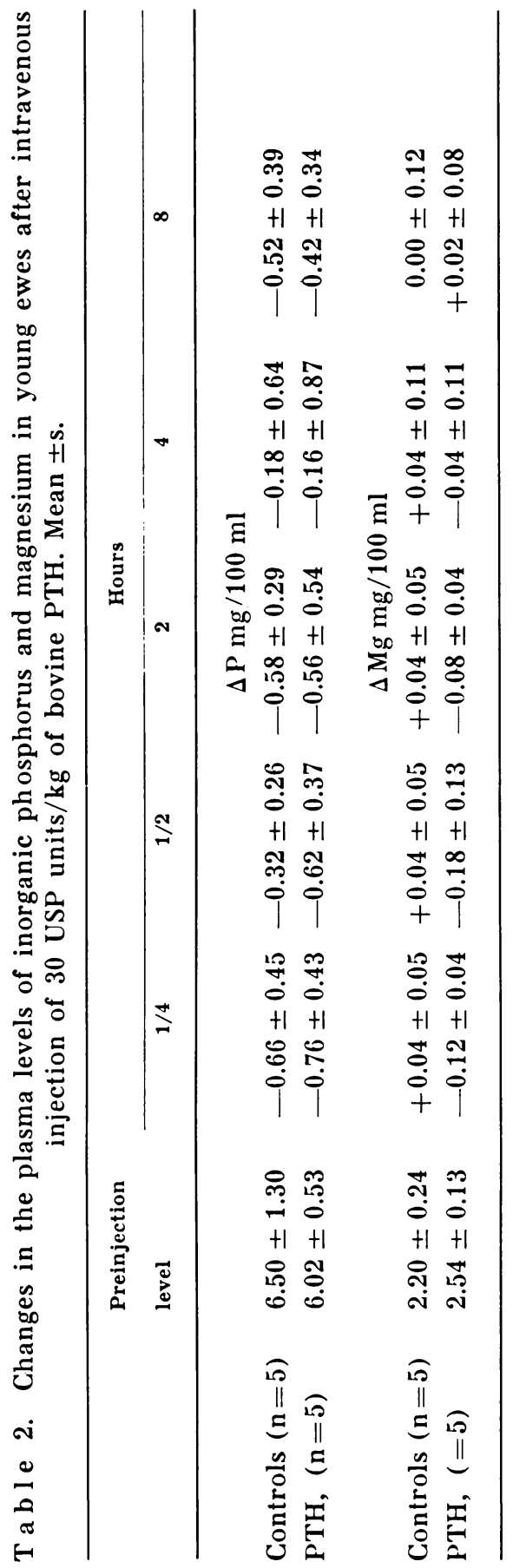




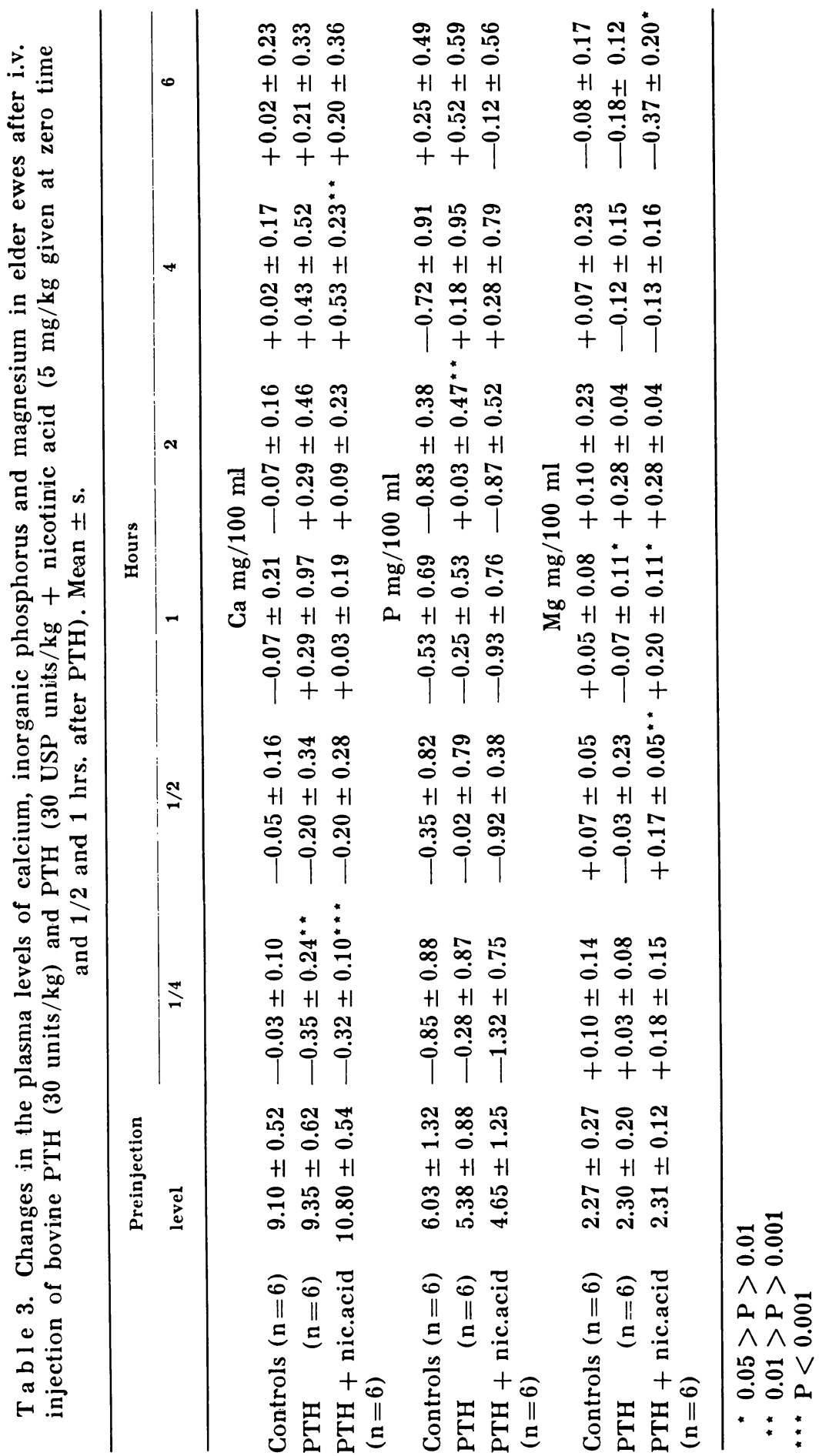




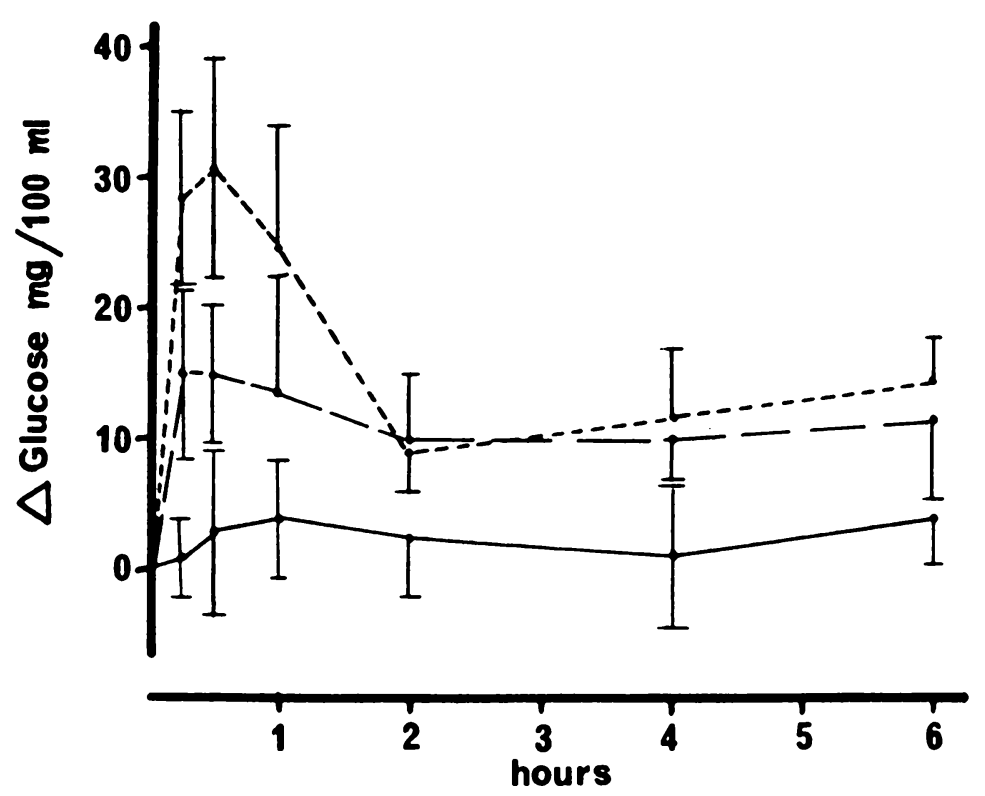

F ig u re 4. Changes in blood glucose after i.v. injection of 30 USP units/kg of bovine PTH _ - , and after i.v. injection of PTH + nicotinic acid $(5 \mathrm{mg} / \mathrm{kg}$ given at $0,1 / 2$ and $1 \mathrm{hr}$.) $\ldots . .$. . Controls Each group consisted of 6 animals. Pretreatment level was $37 \pm 6 \mathrm{mg} / 100 \mathrm{ml}$ in the control group, $36 \pm 4 \mathrm{mg} / 100 \mathrm{ml}$ in the PTH group, and $37 \pm 4 \mathrm{mg} / 100 \mathrm{ml}$ in the PTH + nicotinic acid group. The glucose response to PTH differed significantly $(0.01>P>0.001)$ from that of the controls after $15 \mathrm{~min}$. The difference was almost significant $(0.5>\mathrm{P}>0.01)$ at $1 / 2,1,2,4$ and $6 \mathrm{hrs}$. The difference in response between the controls and the group receiving $\mathrm{PTH}+$ nicotinic acid was highly significant $(P<0.001)$ at $1 / 4,1 / 2,2$ and $6 \mathrm{hrs}$. and significant $(0.01>\mathrm{P}>0.001)$ at 1 and $6 \mathrm{hrs}$. Mean $\pm \mathrm{s}$.

\section{DISCUSSION}

PTH is generally considered as a slow acting hormone. The time of onset of its effects is, however, to a large extent depending on the route of administration. When administered intravenously, PTH alters calcium metabolism rapidly. Laying hens are extremely responsive, and Mueller et al. (1973) obtained a marked hypercalcaemia already after $15-20$ min. The calcium curves obtained in sheep in the present study are in close agreement with those earlier reported in dogs (Parsons et al. 1971). The initial fall in plasma calcium was about $8 \%$ in the sheep, 


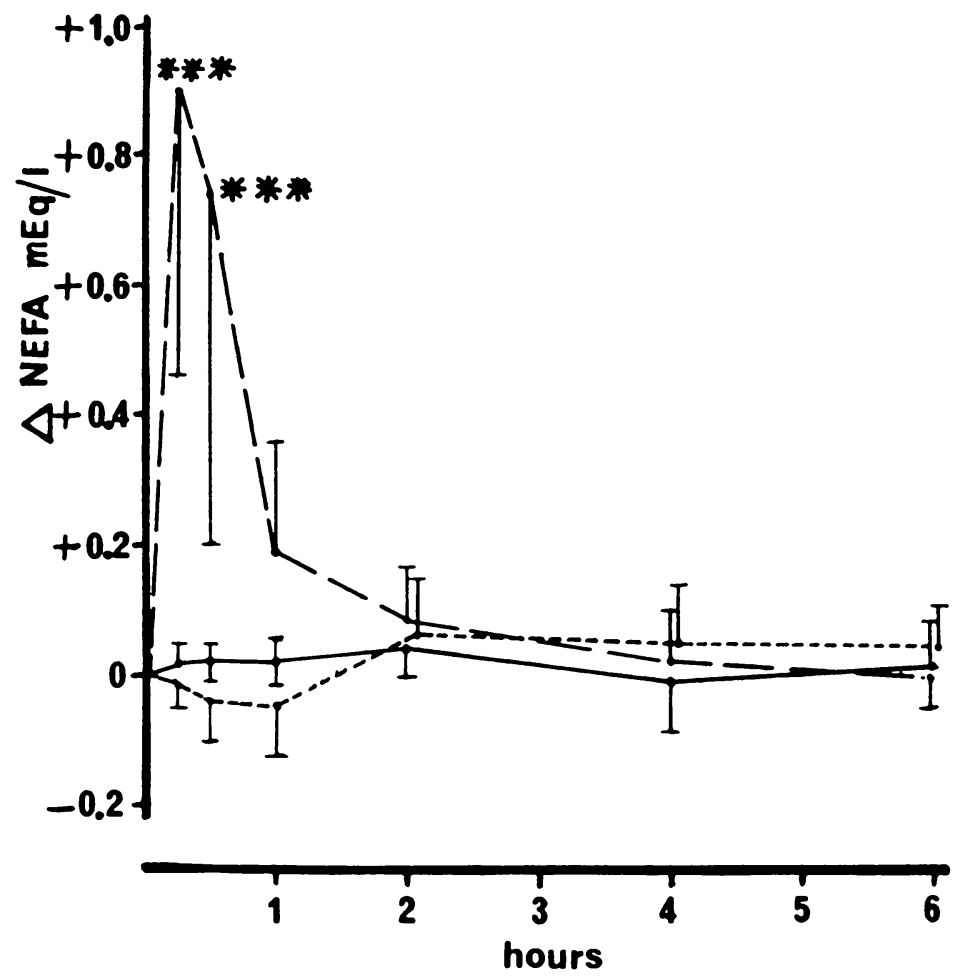

F i g u r e 5. Changes in plasma NEFA after i.v. injection of 30 USP units/kg of bovine PTH - - and PTH + nicotinic acid (5 mg/ $\mathrm{kg}$ given at $0,1 / 2$ and $1 \mathrm{hr} . \ldots .$. . Controls _. Each group consisted of 6 animals. Preinjection level was $0.25 \pm 0.06 \mathrm{meq} . / 1$ in the control group, $0.30 \pm 0.07$ meq. $/ 1$ in the PTH group, and $0.25 \pm 0.06$ meq. $/ \mathrm{l}$ in the PTH + nicotinic acid group. Mean $\pm \mathrm{s}$.

$* * P<0.001$.

in the dog study of Parsons et al. the corresponding change was $4 \%$. The dose used in the present study was 30 USP units/kg, while Parsons et al. used 20 USP units/kg.

The effects of PTH are mediated by the well established adenyl cyclase - cyclic adenosine $3^{\prime} 5^{\prime}$ monophosphate $\left(3^{\prime}, 5^{\prime}\right.$ AMP) system (Chase et al. 1969, Chase \& Aurbach 1970). During recent years it has become evident that calcium ions play an important role in this system. Rasmussen (1972) summarized the knowledge of the effects of various hormones on cellular calcium transport and presented a hypothesis on the interaction between PTH, adenyl cyclase, 3', 5' AMP and calcium ions. Accord- 
ing to this hypothesis, PTH activates adenyl cyclase in the cell membrane and also increase the permeability of the cell membrane to calcium. The activation of adenyl cyclase causes an increased formation of $3^{\prime}, 5^{\prime} \mathrm{AMP}$, which in turn increases the transport of calcium from the calcium rich mitochondria to the cytosol. The calcium concentration in the cytosol is thus increased by transport of extracellular calcium into the cell and by release of calcium from the mitochondria. The increased calcium concentration in the cytosol is considered necessary for the further biochemical processes in the activation of the cell. Since the works of Parsons et al., Parsons \& Robinson (1971) and Robinson et al. (1972), it is generally considered that the immediate hypocalcaemia following intravenous injection of PTH is caused by a shift of calcium into bone. Calcitonin, on the other hand, induces a calcium transport in the opposite direction (Rasmussen \& Feinblatt 1971, Caniggia et al. 1972).

Lipolysis in adipose tissue is a process where the role of calcium also has been studied. Lipolytic agents show decreased or no activity in calcium-free media (Efendic et al. 1970). Akgün \& Rudman (1969) and Moseley \& Axford (1971) reported that the calcium uptake in adipose tissue during excessive lipolysis might be of such an order that the plasma level was reduced. Werner \& Löw (1973) found a weak lipolytic effect of bovine PTH in rat adipose tissue in vitro. PTH-induced lipolysis was associated with increased uptake of calcium into the tissue. The calcium uptake was directly related to the amounts of glycerol released. The requirement of calcium in cell activation is thus not restricted to bone cells, but is probably universal.

As shown in Fig. 3, the hypercalcaemic response to PTH was greater in the thyroidectomized animals than in the intacts. It is obvious that the efficacy of the feed back regulation by calcitonin must be taken into consideration when evaluating the hypercalcaemic response to PTH in intact sheep. Similar observations were made by Barlet (1972) after intravenous infusion of PTH in intact and thyroidectomized steers.

The hypercalcaemic response in the young sheep was of about the same order as reported in dogs by Parsons et al. The PTH dose used in the present study was, however, $50 \%$ higher. It should, however, be noted that PTH did not increase plasma calcium in adult ewes. Whether this lack of effect was due to unresponsiveness of bone or to a very effective feed back regula- 
tion is difficult to evaluate. Administration of PTH and nicotinic acid caused a significant increase in plasma calcium. The mechanism of action of nicotinic acid is difficult to explain. Nicotinic acid per se has no influence on the plasma calcium level (Persson \& Luthman, unpubl.).

The hypercalcaemic response was mast pronounced in the rams. There is evidence that sex hormones influence the action of PTH. Orimo et al. (1972) reported that ovariectomy increased the sensitivity of rat bone to PTH. The effect of calcitonin appears also to be sex dependant. Philippo \& Hinde (1968) found male rats more responsive to calcitonin than females.

The phosphate transport is changed in 2 different ways by PTH. Stimulation of bone resorption is associated with increased outflow of phosphate from bone. In order to prevent hyperphosphataemia, PTH also increases the renal excretion of phosphate. Renal excretion is in general increased to such an extent that hypophosphataemia occurs. The phosphaturic effect of PTH seems, however, not to be coupled to its effect on bone. Stewart $\&$ Bowen (1952) found that treatment with formaldehyde abolished the hypercalcaemic but not the phosphaturic activity of PTE.

Varying changes in the plasma level of inorganic phosphorus have been reported after administration of PTH to ruminants. Lotz et al. (1954) found a rise in plasma inorganic phosphorus in sheep after PTH injection, and Todd et al. (1962) obtained no changes in thyroparathyroidectomized cows. Mayer (1970), on the other hand, reported an acute decline in the plasma phosphate level in cattle after a dose of 5000 USP units/animal. In the dog study of Parsons et al., the changes in plasma inorganic phosphorus followed the changes in plasma calcium. In the present study inorganic phosphorus was significantly lowered in the rams. This group also showed the highest pretreatment level.

As seen from Tables 1, 2 and 3, PTH lowered plasma magnesium significantly which is in agreement with the results of Care et al. (1966) and Haas et al. (1965). PTH + nicotinic acid caused a significant rise in plasma magnesium. At the end of the observation period the magnesium level was, however, significantly lowered. This unexpected response is difficult to explain, since nothing is known about the influence of nicatinic acid on magnesium metabolism. Preliminary studies showed that nicotinic acid alone did not change plasma magnesium. 
PTH showed a remarkable lipolytic effect. In some animals plasma NEFA reached levels of $1.5 \mathrm{meq} . / \mathrm{l}$ after $15 \mathrm{~min}$. The lipolytic effect of PTH in sheep is equal to that of catecholamines (Luthman \& Jonson 1969). PTH-induced lipolysis was completely inhibited by nicotinic acid. Lipolytic activity of PTH in vivo does not seem to have been described earlier.

The slight hyperglycaemic effect of PTH was potentiated by nicotinic acid. A similar interaction between nicotinic acid and norepinephrine was described by Dzedin et al. (1968). In their study in rabbits, nicotinic acid showed a very weak hypercalcaemic effect. Nicotinic acid has no hyperglycaemic effect in sheep (Farges et al. 1971, Luthman \& Jonson, unpubl.).

The acute effects of PTH obtained in the present study are in agreement with the results reported in other species. The lipolytic effect of PTH is of special interest since severe hypocalcaemia very often is associated with elevated NEFA levels (Luthman \& Jonson 1972, Luthman et al. 1972 b). It is possible that PTH is one of the factors responsible for the increased lipolysis.

\section{REFERENCES}

Akgün, S. \& D. Rudman: Relationships between the mobilization of free fatty acids from adipose tissue, and the concentration of calcium in the extracellular fluid and in the tissue. Endocrinology $1969,84,926-930$.

Barlet, J. P.: Calcium homeostasis in the normal and thyroidectomized bovine. Horm. Metab. Res. 1972, 4, 300-303.

Caniggia, A., C. Genneri, F. Piantelli \& A. Vattimo: Initial increase of plasma radioactivity calcium after intravenous injection of calcitonin in man. Clin. Sci. 1972, 43, 1971-180.

Care, A. D., W. M. Keynes \& T. Duncan: An investigation into the parathyroid origin of calcitonin. J. Endocr. 1966, 34, 299-318.

Chase, L. R. \& G. D. Aurbach: The effect of parathyroid hormone on the concentration of adenosine $3^{\prime}, 5^{\prime}$-monophosphate in skeletal tissue in vitro. J. biol. Chem. 1970, 245, 1520-1526.

Chase, L. R., S. A. Fedak \& G. D. Aurbach: Activation of skeletal adenyl cyclase by parathyroid hormone in vitro. Endocrinology $1969,84,761-768$.

Copp, D. H. \& E. C. Cameron: Demonstration of a hypocalcaemic factor (calcitonin) in commercial parathyroid extract. Science $1961,134,2038$.

Copp, D. H., E. C. Cameron, B. A. Cheney, A. G. F. Davidson \& K. G. Henze: Evidence for calcitonin - a new hormone from the parathyroid that lowers blood calcium. Endocrinology 1962, 70, $638-649$. 
Dole, $V$. P.: A relation between non-esterified fatty acid in plasma and the metabolism of glucose. J. clin. Invest. $1956,35,150$ 154.

Dzedin, T., L. Lundholm \& N. Svedmyr: Relationship between some metabolic effects of nicotinic acid and catecholamines in the rabbit. Acta pharmacol. (Kbh.) 1968, 26, 446-460.

Efendic, S., B. Alm \& H. Löw: Effects of $\mathrm{Ca}^{++}$on lipolysis in human omental adipose tissue. Horm. Metab. Res. 1970, 2, 287-291.

Farges, J. P., R. Boivin \& J. Bost: Effects du nicotinate de sodium sur la formation des corps cétoniques chez le mouton. (Effects of sodium nicotinate on the formation of ketone bodies in sheep). Bull. Soc. Sci. vét. Méd. comp. (Lyon) 1971, 73, 411-423.

Haas, H. G., H. Affolter \& U. C. Dubach: Evidence for a calcitonin effect in man. Acta endocr. (Kbh.) 1965, 48, 132-136.

Jackson, H. D., A. R. Pappenhagen, G. D. Goetsch \& C. H. Nolerl: Effect of parathyroid hormone on calcium and other plasma constituents of dairy cattle near parturition. J. Dairy Sci. 1962, 45, 897-903.

Lotz, W. E., R. V. Talmage \& C. L. Cronan: Effect of parathyroid extract administration in sheep. Proc. Soc. exp. Biol. (N. Y.) 1954, $85,292-295$.

Luthman, J. \& G. Jonson: The metabolic response to norepinephrine in carbon tetrachloride poisoned sheep. Acta vet. scand. 1969, $10,168-180$.

Luthman, J. \& G. Jonson: Unpublished observations.

Luthman, $J$. \& $G$. Jonson: The relationship between serum calcium and plasma non-esterified fatty acids in normal and hypocalcemic cows and sheep. Acta vet. scand. 1972, 13, 42-55.

Luthman, J., G. Jonson \& J. Persson: Studies on norepinephrine-induced hypocalcemia in sheep before and after thyroidectomy. Acta vet. scand. 1972 a, 13, 20-30.

Luthman, J., G. Jonson \& J. Persson: Metabolic responses to norepinephrine in hypocalcaemic sheep. Zbl. Met-Med. A 1972 b, 19, $769-774$.

Martig, J. \& G. P. Mayer: Diminished hypercalcaemic response to parathyroid extract in prepartum cows. J. Dairy Sci. 1973, 56, $1042-1046$.

Mayer, G. P.: The roles of parathyroid hormone and thyrocalcitonin in parturient paresis. In Parturient Hypocalcemia. Ed. by J. J. B. Anderson. Acad. Press, New York and London 1970.

Mayer, G. P., C. F. Ramberg Jr. \& D. S. Kronfeld: Calcium metabolism and kinetics in intact and parathyroidectomized cows given parathyroid extract. J. Nutr. 1967, 92, 253-260.

Moseley, G. \& R. F. E. Axford: Redistribution of calcium in sheep induced by stress. Proc. Nutr. Soc. 1971, 30, 58 A.

Mueller, W. J., K. L. Hall, C. A. Maurer Jr. \& I. G. Joshua: Plasma calcium and inorganic phosphate response of laying hens to parathyroid hormone. Endocrinology 1973, 92, 853-856. 
Orimo, H., T. Fujita \& M. Yoshikawa: Increased sensitivity of bone to parathyroid hormone in ovariectomized rats. Endocrinology 1972, 90, 760—763.

Parsons, J. A.\& J. T. Potts Jr.: Physiology and chemistry of parathyroid hormone. In Clinics in Endocrinology and Metabolism. I. Calcium Metabolism and Bone Disease. Ed. by I. MacIntyre. W. B. Saunders Company Ltd., London, Philidelphia, Toronto 1972.

Parsons, J. A.\& C. J. Robinson: Calcium shift into bone causing transient hypocalcaemia after injection of parathyraid hormone. Nature (Lond.) 1971, 230, 581-582.

Parsons, J. A., R. M. Neer \& J. T. Potts Jr.: Initial fall of plasma calcium after intravenous injection of parathyroid hormone. Endocrinology $1971,89,735-740$.

Persson, J. \& J. Luthman: Unpublished observations.

Phillippo, M. \& F. Hinde: Age and sex as factors in the response to thyrocalcitonin. In Calcitonin. Procedings of the symposium on thyrocalcitonin and the C cells, London 1967. Ed. by S. Taylor. W. Heinemann Medical Books Ltd., London 1968.

Rasmussen, H.: The cellular basis of mammalian calcium homeostasis. In Clinics in Endocrinology and Metabolism. I. Calcium Metabolism and Bone Disease. Ed. by I. MacIntyre. W. B. Saunders Company Ltd., London, Philadelphia, Toronto 1972.

Rasmussen, H. \& J. Feinblatt: The relationship between the action of vitamin $\mathrm{D}$, parathyroid hormone and calcitonin. Calcif. Tiss. Res. 1971, 6, 265-279.

Robinson, C. J., B. Rafferty \& J. A. Parsons: Calcium shift into bone: a calcitonin-resistant primary action of parathyroid hormone, studied in rats. Clin. Sci. 1972, 42, 235-241.

Skerry, D. W.: Di-(2-hydroxy-phenyl-imino)ethane: a new indicator for the EDTA titration of serum calcium. Clin. chim. Acta 1965, $12,593-597$.

Stewart, G. S. \& H.F. Bouen: The urinary phosphate excretion factor of parathyroid gland extracts: a hormone or an artefact? Endocrinology $1952,51,80-86$.

Stott, G. H. \& V. R. Smith: Parturient paresis. VIII. Results of parathyroidectomy of cows. J. Dairy Sci. 1957, 40, 897-904.

Tiselius, P., B. Engfeldt, J. Porath, G. Wallenius \& I. Werner: Some preliminary experiments with purified human parathyroid extracts. Metabolism 1964, 13, 929—933.

Todd, A. S., O. T. Fosgate, R. G. Cragle \& T. H. Kamal: Parathyroid action on calcium, phosphorus, magnesium, and citric acid in dairy cattle. Amer. J. Physiol. 1962, 202, 987—990.

Werner, S. \& H. Löw: Stimulation of lipolysis and calcium accumulation by parathyroid hormone in rat adipose tissue in vitro after adrenalectomy and administration of high doses of cortisone acetate. Horm. Metab. Res. 1973, 5, 292—296. 


\section{SAMMANFATTNING}

Akuta metaboliska effekter av parathormon hos får.

Under de senaste åren har det klarlagts att kalciumjoner är nödvändiga för aktivering av ett flertal olika cellsystem. Bl. a. gäller detta parathormonets effekt på skelettet och lipolytiska hormoners effekt på fettvävnaden. I den föreliggande undersökningen användes får för att studera de akuta effekterna på mineral- och fettmetabolismen efter intravenös injektion av parathormon (PTH). PTH medförde en signifikant initial hypokalcemi i samtliga grupper av djur. Den därpå följande hyperkalcemin var störst hos baggar, skillnaden i kalciumsvar mellan unga baggar och unga tackor var nästan signifikant. Hyperkalcemin var större hos thyreoidektomerade djur än hos intakta. Den lipolytiska effekten av PTH var kraftig, jämförbar med katekolamin-inducerad lipolys, medan glykosstegringen endast var ringa. Det lipolytiska svaret blockerades av nikotinsyra, medan hyperglykemin potentierades. Hypofosfatemi påvisades hos unga baggar, däremot inte hos unga tackor, och hos äldre tackor erhölls en liten stegring av halten oorganiskt fosfor. I samtliga grupper medförde PTH hypomagnesemi, medan PTH + nikotinsyra gav hypermagnesemi. De erhållna resultaten diskuteras med utgångspunkt från den aktuella kunskapen om mineral- och fettmetabolismen.

(Received February 11, 1974).

Reprints may be requested from: J. Persson, Department of Medicine II, Royal Veterinary College, S-104 05 Stockholm 50, Sweden. 